\title{
Effects of geographic origin on growth and food intake in Eurasian perch (Perca fluviatilis L.) juveniles under intensive culture conditions
}

\author{
S.N.M. Mandiki ${ }^{\mathrm{a}, *}$, G. Blanchard ${ }^{\mathrm{a}}$, C. Mélard ${ }^{\mathrm{b}}$, J. Koskela ${ }^{\mathrm{c}}$, \\ D. Kucharczyk ${ }^{\mathrm{d}}$, P. Fontaine ${ }^{\mathrm{e}}$, P. Kestemont ${ }^{\mathrm{a}}$

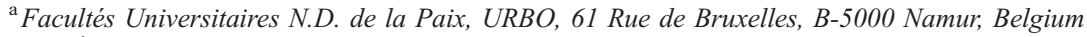 \\ ${ }^{\mathrm{b}}$ Université de Liège, CEFRA, Chemin de la Justice, 10, B-4500 Tihange, Belgium \\ ${ }^{\mathrm{c}}$ Finnish Game and Fisheries Research Institute (FGFRI), Laukaa Fisheries Research and Aquaculture, \\ FIN-41360 Valkola, Finland \\ ${ }^{\mathrm{d}}$ University of Warmia and Mazury in Olsztyn, Department of Lake and River Fisheries, \\ 10-718 Olsztyn-Kortowo, Poland \\ ${ }^{\mathrm{e}}$ Laboratoire de Sciences Animales, INPL-UHP Nancy 1, MAN, 34 Rue Sainte Cathérine, 5400 Nancy, France
}

Received 29 October 2002; received in revised form 7 April 2003; accepted 8 April 2003

\begin{abstract}
Survival, growth, and food intake of Eurasian perch (Perca fluviatilis) juveniles from different stocks originating from various geographic regions of Europe were compared under the same conditions of laboratory-scale intensive culture. In Experiment 1, four stocks originating from Italy (I), southwest (SF) and northwest (NF) France, and Belgium (B) were examined at larval and early juvenile (initial body weight, $\mathrm{IBW}=0.53 \mathrm{~g}$ ) stages. In Experiment 2, B stock was compared to a Finnish $(\mathrm{F})$ one in two trials, including small (IBW=1.26 g) and large (IBW=32 g) juveniles. In Experiment 3, small $(\mathrm{IBW}=1.29 \mathrm{~g})$ and large $(\mathrm{IBW}=7.33 \mathrm{~g})$ juveniles from Polish (P), F, and B stocks were examined. In Experiment 1, body weight means at hatching and survival at the end of the larval stage were significantly lower in the I and SF stocks than in the $\mathrm{B}$ and NF stocks. In the early juvenile stage, survival and growth rates were significantly lower in the I and SF stocks than in the B and NF ones. In Experiment 2, \{early juvenile stage survival in the F stock was significantly lower than in the B stock, partly due to a higher incidence of cannibalism. During this stage, growth rates and food intake or feed efficiency in the F and B stocks were comparable, but at the end of the juvenile stage, the F stock outperformed the B one. In Experiment 3, survival in all the three stocks was comparable both in small and large juveniles.
\end{abstract}

\footnotetext{
* Corresponding author. Tel.: +32-81-724284; fax: +32-81-724362.
}

E-mail address: Robert.Mandiki@fundp.ac.be (S.N.M. Mandiki). 
In contrast to the higher performance of $\mathrm{F}$ juveniles in Experiment 2, growth rates were comparable between the $\mathrm{B}$ and $\mathrm{F}$ stocks, and fish from the $\mathrm{P}$ stock had the highest growth rates. The results indicate a high level of variation within and between hatchery stocks in survival rates, growth rates, and food intake. These variations depended on the geographic origin of the fish, with the lowest survival and growth potentials being in the stocks originating from the southern regions. These findings highlight the interest in evaluating growth and food consumption of different Eurasian perch stocks. Such evaluation is a necessary tool for genetic selection in improving performance in perch aquaculture.

(C) 2004 Elsevier Science B.V. All rights reserved.

Keywords: Growth; Food intake; Perch; Perca fluviatilis; Stocks; Juveniles

\section{Introduction}

Until now, Eurasian perch (Perca fluviatilis) larvae have been mainly obtained from wild breeders, without any genetic selection that would result in improved survival and growth performances in culture conditions. Consequently, high year-by-year variations are observed according to the genetic quality of captured parental individuals. Apart from low survival at different developmental stages, the development of intensive culture of Eurasian perch is strongly limited by slow juvenile growth compared to that of other fish species (Kestemont and Dabrowski, 1996; Grignard et al., 1996a,b; Kestemont et al., 1996; Mélard et al., 1996; Fontaine et al., 1997; Tamazouzt et al., 2000).

Wild populations of Eurasian perch are characterised by dynamic and annual fluctuations of abundance that depend on environmental and intra-stock mechanisms (Tyutyunov et al., 1993; Craig, 2000; Romare, 2000). Variations in these features may be the reason for differences in the biological characteristics of perch originating from various geographic regions. It is well known that Eurasian perch abundance levels are higher in northern biotopes than in southern ones, although thermal conditions in the latter would seem to be more optimal for perch growth. Using mitochondrial DNA variation and multilocus DNA fingerprinting, previous studies demonstrated a strong geographic structuring of northern perch populations, with a higher level of genetic variability among certain populations (Nesbø et al., 1998, 1999). Since Nesbø et al. (1999) confirmed the hypothesis that perch colonised southern and northern regions of Europe via different routes, it may be assumed that wild perch populations from southern Europe are genetically different from those in northern areas. Yet so far, no information is available about the growth characteristics of different Eurasian perch populations kept under aquaculture conditions. Therefore, knowledge of survival and growth differences between different perch stocks is necessary as a tool for developing perch intensive aquaculture through genetic selection.

The objective of the present study was to compare - under similar conditions of intensive culture - survival and growth performances as well as food intake in Eurasian perch juveniles from the following European geographic locations: Finland, Poland, France, Belgium, and Italy. 


\section{Materials and methods}

\subsection{Rearing conditions and feeding}

Three experiments, each consisting of two developmental juvenile or larvae stages, were carried out at the indoor facilities of the University of Namur, Belgium $\left(50^{\circ} 25^{\prime} \mathrm{N}\right.$; $5^{\circ} 2^{\prime} \mathrm{E}$ ). The experiments were conducted in a recirculation system with a water flow of ca. $21 \mathrm{~min}^{-1}$ through each tank, a temperature of $22-23^{\circ} \mathrm{C}$, and dissolved oxygen ranging between 6 and $9 \mathrm{mg} \mathrm{O} \mathrm{O}^{-1}$. Water was $\mathrm{UV}$ treated, and $\mathrm{N}-\mathrm{NH}_{4}^{+}$and $\mathrm{N}-\mathrm{NO}_{2}^{-}$ concentrations were $0.04-0.126$ and $0.15-0.20 \mathrm{mg}^{-1}$, respectively. Trout feed was distributed to small juveniles (BioMar-Ecostart nos. 1-2: $51-45 \%$ crude protein, $18-20 \%$ crude fat, $9.0 \%$ ash, and $0.7-1 \%$ crude fibre [contents]) and to large juveniles (BioMarAqualife nos. $2-3$ : $22-20 \%$ fat, $45-42 \%$ crude protein, $8.6-9 \%$ ash, and $1-2 \%$ crude fibre [contents]) by automatic feeders during daylight hours $(0700-2100 \mathrm{~h})$.

\subsection{Experiment 1}

Two trials were carried out in order to compare two southern stocks to two northern ones. The southern parental individuals were captured in Guyenne Pond in southwest France (SF) $\left(44^{\circ} 30^{\prime} \mathrm{N} ; 1^{\circ} 10^{\prime} \mathrm{E}\right)$ and in Lake Trasimene in southern Italy (I) $\left(43^{\circ} 9^{\prime} \mathrm{N}\right.$; $\left.12^{\circ} 6^{\prime}>\mathrm{E}\right)$. The two northern stocks originated from Lindre Pond in northeast France (NF) $\left(48^{\circ} 45^{\prime} \mathrm{N} ; 6^{\circ} 40^{\prime} \mathrm{E}\right)$ and from the upper Meuse River in Belgium (B). After capture, the B breeders were held in 750-1 circular indoor tanks at $12^{\circ} \mathrm{C}$. The I, SF, and NF breeders were held in $40-\mathrm{m}^{3}$ outdoor net cages and exposed to natural temperature. A spawning substrate of spruce twigs was placed in the cage, and when spawning was detected, the twigs with eggs were removed. For each brood fish, 10 different strands of fertilised eggs were collected 2 or 3 days after capture. These were then transferred to the indoor facilities of the University of Nancy for incubation $\left(15-17^{\circ} \mathrm{C}\right)$. The eggs hatched on different but relatively close dates: April 15, 17, 18, and 22, 1997.

In a trial lasting 42 days (trial 1), the growth performances of larvae of the four different stocks were compared. The experiment was conducted in two tanks/stock with 7200 fish in each 500-1 tank. During the first 17 days, the larvae were fed with Artemia nauplii, and subsequently, live food was progressively replaced by an artificial dry diet (BioMarEcostart no. 1: $51 \%$ crude protein, $18 \%$ crude fat, $9.0 \%$ ash, and $0.7 \%$ crude fibre [contents]). Dead fish were removed daily. A random sample of 50 larvae was taken from each tank weekly for growth evaluation. In a trial lasting 79 days (trial 2), the growth performances of small juveniles (IBW $=0.53 \mathrm{~g}$ ) of the four different stocks were compared. The experiment was conducted in three tanks/stock with 922 fish in each 120-1 tank. Dead fish were removed daily as in trial 1, and the biomass was measured biweekly.

\subsection{Experiment 2}

In this experiment, the growth performances of small and large juveniles from the B stock and from a Finnish (F) one were compared. Breeders (B) were captured in the upper Meuse River, Belgium, and in the southwest Finnish Archipelago of the Baltic Sea $\left(60^{\circ} 33^{\prime} \mathrm{N}\right.$; 
$\left.21^{\circ} 41^{\prime} \mathrm{E}\right)$. Next, fertilised egg strands were obtained as in Experiment 1. B and F larvae hatched on April 25 and on June 2, 1999, respectively. Larvae were initially cultured in 3001 square tanks at $22-23^{\circ} \mathrm{C}$ and fed during the first 17 days with Artemia nauplii. Then, live food was progressively replaced by artificial dry feed (BioMar-Ecostart no. 1).

In a trial lasting 120 days (trial 1), the growth performances of small juveniles (IBW $1.26 \mathrm{~g}$ ) were compared. The experiment was conducted in six tanks/stock with 150 fish in each 50-1 tank. Dead fish were removed daily, and actual survival and the biomass were monitored biweekly. In a trial lasting 74 days (trial 2), the growth performances of large juveniles (IBW=32 g) from the same stocks were compared. The experiment was conducted in three tanks/stock with 13 fish in each 100-1 tank. In this trial, fish were individually tagged with passive transponders (PIT-tag, TROVAN, $11 \times 2.1 \mathrm{~mm}, 100 \mathrm{mg}$ ) implanted into the peritoneal cavity as described by Baras et al. (2000). Tagging was performed 3 weeks before the start of the experiment. During the trial, fish were fed by hand to satiation at $0900 \mathrm{~h}$ with trout food. The food was prepared from normal feed by first grinding and then compressing it back into pellets to avoid possible differences in the physical characteristics or palatability of the diet as compared to the labelled food used for measuring food intake. Food consumption was estimated biweekly by the X-ray method previously described (Talbot and Higgins, 1983; Carter et al., 1992). The diet used for feed intake measurements was prepared from a sample of the normal feed by grinding, homogenisation, and incorporation of a known quantity $(2.5 \%$ of weight $)$ of X-ray-dense glass beads ("ballotini”, Silibeads type H, mean diameter $400 \mu \mathrm{m}$, DLO equipment, Belgium), followed by compression into pellets. One hour after feeding, the fish were anaesthetised (120 $\mathrm{mg}^{-1}$ MS 222, Sigma) and X-rayed (TR 80/20 portable X-ray unit, Todd Research, UK, Kodak X-OMAT-MA $24.5 \times 30 \mathrm{~cm}$ film), the films were developed, and the glass beads were counted in the digestive tract of the fish. A calibration curve ( $\left.y=0.0074 x+0.0028, R^{2}=0.96\right)$ describing the relationship between the number of glass beads $(x)$ and the amount of feed ( $y$, in grams) enabled an estimation of food consumption.

\subsection{Experiment 3}

Small and large juveniles from B and F stocks were compared to those of a Polish one (P). The B and F breeders were captured in the same respective areas as in Experiment 2. Next, fertilised egg strands were obtained as in Experiment 1, and the larvae hatched on May 27, 2000. The P breeders were captured in Kortowskie Lake in northern Poland $\left(53^{\circ} 46^{\prime} \mathrm{N} ; 20^{\circ} 29^{\prime} \mathrm{E}\right)$ and were kept under hatchery conditions. Gametes were obtained through artificial spawning. The spawners received a total dose of $1000 \mathrm{IU}$ of hCG per kilogram (Kucharczyk et al., 1996). Fertilised eggs were incubated at $15^{\circ} \mathrm{C}$, and the larvae hatched on June 4, 2000. Due to transportation problems between Poland and Belgium, the $\mathrm{P}$ larvae were initially reared in Poland using a recirculating rearing system (Kujawa et al., 2000), 60-1 tanks, and a water temperature of $24^{\circ} \mathrm{C}$. The larvae were fed Artemia nauplii for 20 days, and then live food was progressively replaced by an artificial dry diet (BioMar-Ecostart no. 1). The fry $(0.4-0.8 \mathrm{~g})$ were transported to Belgium, where they were used for trials after 2 months of acclimatisation.

In a first trial that lasted 112 days, the growth performances of small juveniles $(\mathrm{IBW}=1.32 \mathrm{~g})$ of the three different stocks were compared. The experiment was 
conducted in three tanks/stock with 36 fish in each 50-1 tank. In a second trial that lasted 180 days, the growth performances of large juveniles (IBW=7.33 g) of the three different stocks were compared. The experiment was conducted in three tanks/stock with 33 fish in each 100-1 tank. In both trials, survival, biomass, and feed supplied were measured biweekly as previously described in Experiment 2.

\subsection{Methods}

Dead fish were removed daily, and the difference between the actual number of survivors and the initial amount minus the number of dead fish was considered to be the number of cannibalised fish. Survival (\%) was calculated according to $100 \times\left(N_{\mathrm{i}}-N_{\mathrm{f}}\right) \times N_{\mathrm{i}}^{-1}$ and cannibalism (\%) according to $100 \times\left(N_{\mathrm{i}}-\left(N_{\mathrm{f}}-N_{\mathrm{d}}\right)\right) \times N_{\mathrm{i}}^{-1}$, where $N_{\mathrm{i}}$ and $N_{\mathrm{f}}$ are the initial and final numbers of fish, and $N_{\mathrm{d}}$ is the number of dead fish observed during the experiment. Weight gain was calculated by weighing the tank biomass (Experiments 1 and 3) or individuals (Experiment 2) at the start of each trial and then every 2 weeks. Specific growth rate $\left(\mathrm{SGR} \%\right.$ day $\left.^{-1}\right)$ was calculated as $100 \times\left(\ln W_{2}-\ln W_{1}\right) \times \Delta T^{-1}$, where $W_{1}$ and $W_{2}$ are the initial and final mean body weights, and $\Delta T$ is the time interval (days) between weighings. Body weight variation was assessed by calculating the coefficient of variation $\mathrm{CV} \%=100 \times($ S.D. $) \times(\text { mean })^{-1}$ based on individual data in each group. The amount of food supplied to each group was checked daily and was calculated using the model presented by Mélard et al. (1996), with rations being adjusted after each weighing. In Experiment 2, food intake was expressed in absolute units (grams) and relative to body weight (relative food intake, RFI, \% of body weight). The individual share of a meal (SM) was calculated for each fish as the percentage of cumulative consumption by the group (McCarthy et al., 1992): $\mathrm{SM}=100 \times(\mathrm{Cn} / \Sigma C)$, where $\mathrm{Cn}$ is food consumed by an individual, and $\Sigma C$ is the

Table 1

Experiment 1. Survival and growth rate means ( \pm S.D.) of larvae (trial 1) and small juveniles (trial 2) obtained from four stocks (I: Italy; NF: northwest France; SF: southeast France; B: Belgium) of Eurasian perch, $P$. fluviatilis, and cultured under intensive conditions

\begin{tabular}{|c|c|c|c|c|}
\hline & I & NF & SF & $\mathrm{B}$ \\
\hline \multicolumn{5}{|l|}{ Survival (\%) } \\
\hline Trial 1 & $80 \pm 1^{\mathrm{a}}$ & $96 \pm 6^{b}$ & $71 \pm 6^{\mathrm{a}}$ & $99 \pm 1^{b}$ \\
\hline Trial 2 & $19 \pm 3^{\mathrm{a}}$ & $37 \pm 4^{\mathrm{b}}$ & $24 \pm 4^{\mathrm{a}}$ & $30 \pm 5^{\mathrm{b}}$ \\
\hline \multicolumn{5}{|c|}{ Initial body weight (IBW) } \\
\hline Trial 1 (mg) & $0.55 \pm 0.03^{\mathrm{a}}$ & $0.64 \pm 0.04^{\mathrm{a}}$ & $0.49 \pm 0.15^{\mathrm{b}}$ & $0.86 \pm 0.01^{\mathrm{c}}$ \\
\hline Trial $2(\mathrm{~g})$ & $0.55 \pm 0^{\mathrm{a}}$ & $0.59 \pm 0^{\mathrm{a}}$ & $0.62 \pm 0^{\mathrm{a}}$ & $0.37 \pm 0^{\mathrm{b}}$ \\
\hline \multicolumn{5}{|c|}{ Final body weight (FBW) } \\
\hline Trial 1 (mg) & $233 \pm 4^{\mathrm{a}}$ & $219 \pm 42^{\mathrm{a}}$ & $235 \pm 24^{\mathrm{a}}$ & $211 \pm 5^{\mathrm{a}}$ \\
\hline Trial $2(\mathrm{~g})$ & $3.35 \pm 0.21^{\mathrm{a}}$ & $4.84 \pm 0.52^{b}$ & $3.75 \pm 0.04^{\mathrm{a}}$ & $4.30 \pm 0.37^{\mathrm{b}}$ \\
\hline \multicolumn{5}{|c|}{ Specific growth rate $S G R\left(\%\right.$ day $\left.{ }^{-1}\right)$} \\
\hline Trial 1 & $14.45 \pm 011^{\mathrm{a}}$ & $13.87 \pm 0.62^{\mathrm{a}}$ & $14.99 \pm 0.67^{\mathrm{a}}$ & $13.12 \pm 0.04^{\mathrm{a}}$ \\
\hline Trial 2 & $2.28 \pm 0.07^{\mathrm{a}}$ & $2.67 \pm 0.14^{b}$ & $2.27 \pm 0.01^{\mathrm{a}}$ & $3.10 \pm 0.11^{\mathrm{b}}$ \\
\hline
\end{tabular}

Values (in row) with different superscript letters are significantly different $(P<0.05)$. 
cumulative consumption by the group. Intra- and inter-individual variations in food intake were calculated using consumption data recorded on five different dates (from March 24 to May 24). Intra-individual food consumption variation was calculated as the variation of an individual's consumption compared to the mean of five meals, whereas inter-individual feed intake variation represents variation between group members. Feed efficiency (FE) was calculated as weight gain/feed intake.

\section{Statistical analysis}

Values, expressed as mean \pm S.D., were compared using ANOVA followed by a post hoc PLSD test, and null hypotheses were rejected at $P<0.05$. In Experiment 2, the correlation was calculated between final body weights, specific growth rate, intra-individual food

Table 2

Experiment 2. Survival, growth parameter, and food intake means ( \pm S.D.) of small (trial 1) and large (trial 2) juveniles obtained from two stocks (B: Belgium; F: Finland) of Eurasian perch, P. fluviatilis, and cultured under intensive conditions

\begin{tabular}{|c|c|c|}
\hline & $\mathrm{B}$ & $\mathrm{F}$ \\
\hline \multicolumn{3}{|c|}{ Survival (\%) } \\
\hline Trial 1 & $71 \pm 4^{\mathrm{a}}$ & $54 \pm 10^{\mathrm{b}}$ \\
\hline Trial 2 & $87 \pm 16^{\mathrm{a}}$ & $74 \pm 4^{\mathrm{a}}$ \\
\hline \multicolumn{3}{|c|}{ Cannibalism (\%) } \\
\hline Trial 1 & $0.7 \pm 1.8^{\mathrm{a}}$ & $2.0 \pm 2.1^{\mathrm{b}}$ \\
\hline Trial 2 & 0 & 0 \\
\hline \multicolumn{3}{|c|}{ Final body weight $(F B W, g)$} \\
\hline Trial 1 & $16.25 \pm 1.47^{\mathrm{a}}$ & $14.91 \pm 1.10^{\mathrm{a}}$ \\
\hline Trial 2 & $50.73 \pm 1.27^{\mathrm{a}}$ & $62.24 \pm 4.77^{\mathrm{b}}$ \\
\hline \multicolumn{3}{|c|}{ Growth heterogeneity $\left(C V_{F B W} / C V_{I B W}\right)$} \\
\hline Trial 1 & $1.74 \pm 0.12^{\mathrm{a}}$ & $1.50 \pm 0.06^{\mathrm{a}}$ \\
\hline Trial 2 & $1.25 \pm 0.24^{\mathrm{a}}$ & $0.99 \pm 0.04^{\mathrm{a}}$ \\
\hline \multicolumn{3}{|c|}{ Specific growth rate, SGR $\left(\%\right.$ day $\left.{ }^{-1}\right)$} \\
\hline Trial 1 & $2.33 \pm 0.59^{\mathrm{a}}$ & $2.07 \pm 0.53^{\mathrm{a}}$ \\
\hline Trial 2 & $0.89 \pm 0.46^{\mathrm{a}}$ & $1.20 \pm 0.34^{\mathrm{b}}$ \\
\hline \multicolumn{3}{|c|}{ Feed efficiency } \\
\hline Trial 1 & $0.73 \pm 0.13^{\mathrm{a}}$ & $0.76 \pm 0.17^{\mathrm{a}}$ \\
\hline Trial 2 & $0.55 \pm 0.62^{\mathrm{a}}$ & $0.66 \pm 0.42^{\mathrm{b}}$ \\
\hline \multicolumn{3}{|c|}{ Feed consumption } \\
\hline \multicolumn{3}{|c|}{ Intra-individual feed intake (intra-FI, $\mathrm{g}$ fish ${ }^{-1}$ ) } \\
\hline Trial 2 & $0.66 \pm 0.08^{\mathrm{a}}$ & $0.77 \pm 0.12^{\mathrm{b}}$ \\
\hline \multicolumn{3}{|c|}{ Inter-individual feed intake (inter-FI, $\mathrm{g}$ fish ${ }^{-1}$ ) } \\
\hline Trial 2 & $0.67 \pm 0.10^{\mathrm{a}}$ & $0.79 \pm 0.12^{b}$ \\
\hline
\end{tabular}

Values (in row) with different superscript letters are significantly different $(P<0.05)$. 
intake \{variation\}, and mean share of meal. The data were expressed in percentages and were log-transformed before calculations with the software package Statistica 5.5.

\section{Results}

\subsection{Experiment 1}

After the larval and early juvenile stages, survival was lower in the southern stocks (I and SF) than in the northern ones (NF and B, Table 1). Mean body weight at hatching was highest in stock B and lowest in stock SF. During the larval stage, growth rates did not significantly differ between stocks (Table 1). In contrast, in small
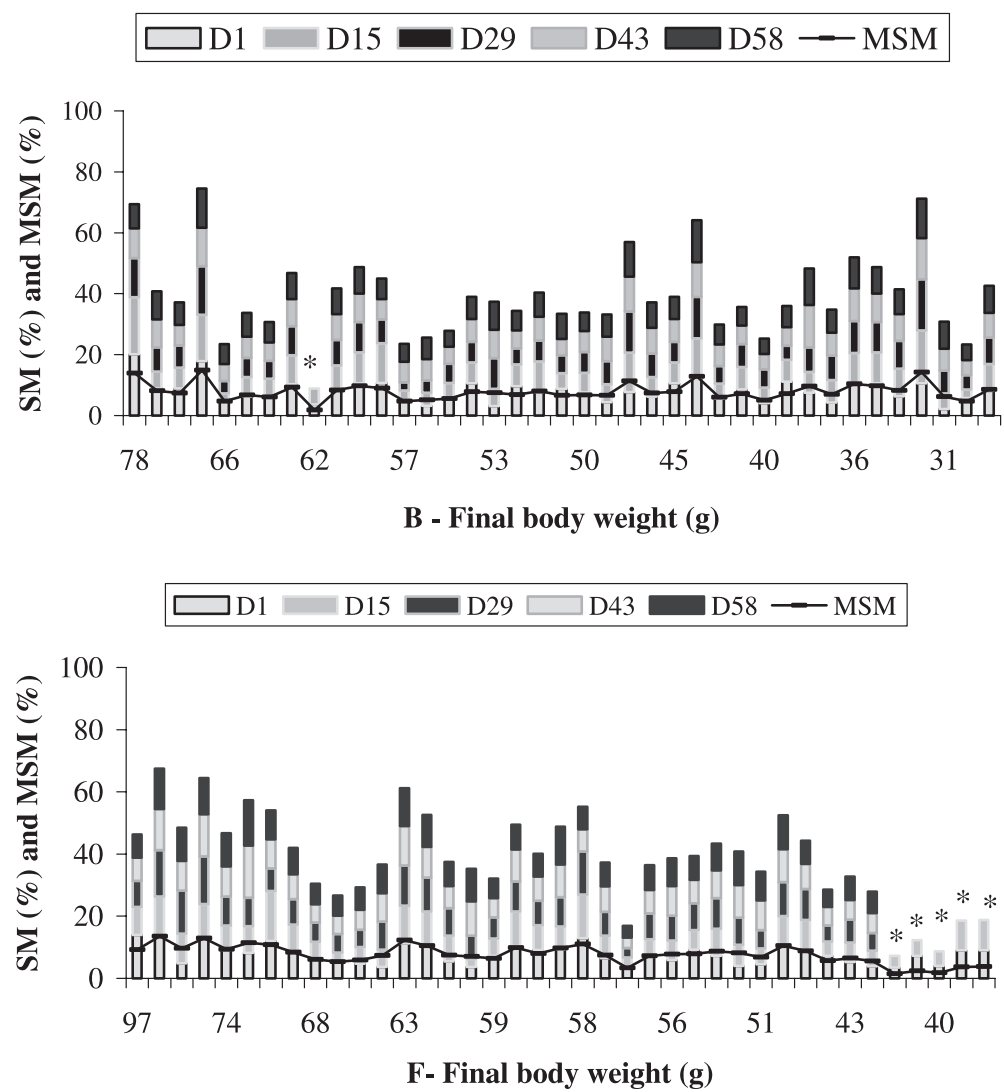

Fig. 1. Relation between mean share of a meal and individual body weight in large juveniles obtained from two different stocks (Experiment 2, trial 2, B: Belgium; F: Finland) of Eurasian perch, P. fluviatilis, and cultured under intensive conditions. The values represent the cumulative individual share of a meal (bars, SM) and the mean share of a meal (line, MSM) on the five sampling dates. Fish were ranked according to final body weight from the highest to the lowest value. *Dead fish on day 15 and 29 of the experiment. 
juveniles, growth rates were higher in the northern stocks than in the southern ones (Table 1).

\subsection{Experiment 2}

In small juveniles (mean initial body weight, IBW \pm S.D. $=1.27 \pm 0.07 \mathrm{~g}$ ), survival was lower in F stock than in B stock, partly due to a higher incidence of cannibalism in $\mathrm{F}$ stock (Table 2). In large juveniles (initial body weight \pm S.D. $=31.79 \pm 1.77 \mathrm{~g}$ ), survival did not significantly differ between $\mathrm{F}$ and $\mathrm{B}$ stocks, and no cannibalism was observed. In small juveniles, the growth heterogeneity $\left(\mathrm{CV}_{\mathrm{FBW}} / \mathrm{CV}_{\mathrm{IBW}}\right)$, growth rate, and feed efficiency did not significantly differ between the two stocks. In contrast, in large juveniles, growth rate and feed efficiency were higher in F stock than in B stock, but there was no significant difference in growth rate heterogeneity. For both stocks, the FBW values were positively $(P<0.05)$ correlated to SGR $(r=0.64$ and 0.69 for $\mathrm{F}$ and $\mathrm{B}$, respectively). Food consumption was significantly $(P<0.05)$ higher in $\mathrm{F}$ than in $\mathrm{B}$ large juveniles, as indicated by intra- and inter-individual food intake $\left(0.77 \mathrm{vs} .0 .66 \mathrm{~g}\right.$ fish $^{-1}$ and 0.79 vs. $0.67 \mathrm{~g}_{\text {fish }}{ }^{-1}$ ). Individual share of the meal was not related to individual body weight (Fig. 1), but significant positive correlation was calculated between intra-individual

Table 3

Experiment 3. Survival and growth parameter means ( \pm S.D.) of small (trial 1) and large (trial 2) juveniles obtained from three stocks (B: Belgium; F: Finland; P: Poland) of Eurasian perch, P. fluviatilis, and cultured under intensive conditions

\begin{tabular}{|c|c|c|c|}
\hline & $\mathrm{B}$ & $\mathrm{P}$ & $\mathrm{F}$ \\
\hline \multicolumn{4}{|c|}{ Survival (\%) } \\
\hline Trial 1 & $77 \pm 11^{\mathrm{a}}$ & $79 \pm 3^{\mathrm{a}}$ & $80 \pm 9^{\mathrm{a}}$ \\
\hline Trial 2 & $91 \pm 4^{\mathrm{a}}$ & $89 \pm 2^{\mathrm{a}}$ & $89 \pm 2^{\mathrm{a}}$ \\
\hline \multicolumn{4}{|c|}{ Cannibalism (\%) } \\
\hline Trial 1 & $0.55 \pm 0.90^{\mathrm{b}}$ & $0.32 \pm 3.0^{\mathrm{a}}$ & $0.66 \pm 0.25^{\mathrm{b}}$ \\
\hline Trial 2 & $0.3 \pm 0.4^{\mathrm{a}}$ & $0.2 \pm 0.1^{\mathrm{a}}$ & $0.3 \pm 0.3^{\mathrm{a}}$ \\
\hline \multicolumn{4}{|c|}{ Final body weight $(F B W, g)$} \\
\hline Trial 1 & $17.20 \pm 4.24^{\mathrm{a}}$ & $20.64 \pm 4.45^{\mathrm{b}}$ & $11.32 \pm 4.83^{\mathrm{c}}$ \\
\hline Trial 2 & $63.00 \pm 7.21^{\mathrm{ab}}$ & $68.00 \pm 0.24^{\mathrm{b}}$ & $55.79 \pm 4.93^{\mathrm{a}}$ \\
\hline \multicolumn{4}{|c|}{ Growth heterogeneity $\left(C V_{F B W} / C V_{I B W}\right)$} \\
\hline Trial 1 & $0.96 \pm 0.12^{\mathrm{a}}$ & $0.88 \pm 0.16^{\mathrm{a}}$ & $1.10 \pm 0.8^{\mathrm{a}}$ \\
\hline Trial 2 & $0.78 \pm 0.08^{\mathrm{a}}$ & $0.76 \pm 0.05^{\mathrm{a}}$ & $1.00 \pm 0.06^{\mathrm{a}}$ \\
\hline \multicolumn{4}{|c|}{ Specific growth rate, SGR $\left(\%\right.$ day $\left.{ }^{-1}\right)$} \\
\hline Trial 1 & $2.12 \pm 0.85^{\mathrm{a}}$ & $2.62 \pm 0.26^{\mathrm{b}}$ & $2.15 \pm 0.26^{\mathrm{a}}$ \\
\hline Trial 2 & $1.06 \pm 0.17^{\mathrm{b}}$ & $1.62 \pm 0.22^{\mathrm{a}}$ & $1.24 \pm 0.15^{\mathrm{b}}$ \\
\hline \multicolumn{4}{|c|}{ Feed efficiency } \\
\hline Trial 1 & $0.51 \pm 0.17^{\mathrm{b}}$ & $0.70 \pm 0.17^{\mathrm{a}}$ & $0.42 \pm 0.19^{b}$ \\
\hline Trial 2 & $0.51 \pm 0.17^{\mathrm{a}}$ & $0.64 \pm 0.13^{\mathrm{a}}$ & $0.62 \pm 0.09^{\mathrm{a}}$ \\
\hline
\end{tabular}

Values (in row) with different superscript letters are significantly different $(P<0.05)$. 
food intake and FBW in F $(r=0.74, P<0.01)$, but not in $\mathrm{B}(r=0.22, P>0.05)$. In the latter stock, fish with high food intake had the least variable consumption and significant positive correlation was calculated between intra-individual food intake and its $\mathrm{CV} \%$ $(r=0.66, P<0.01)$.

\subsection{Experiment 3}

Both in small and large juveniles, survival was comparable among all the three stocks. In small fish, cannibalism was lower in P stock than in other ones, but in large juveniles, there was no difference between stocks (Table 3). Small and large juveniles of P stock had the highest growth rate. In contrast to the higher performance of $F$ juveniles in Experiment 2 , growth rates were comparable between the B and F stocks. Growth heterogeneity was comparable between stocks both in small and large juveniles (Table 3). In small, but not in large juveniles, food efficiency differed significantly between different stocks, with the highest values appearing in the $\mathrm{P}$ stock.

\section{Discussion}

The results of Experiment 1 in the present study show that, compared to the larval stage, survival decreased significantly in all stocks in the early juvenile stage. An increase in mortality at that developmental stage as a result of changes in feeding has been previously reported (Kestemont et al., 1996; Mélard et al., 1996; Fontaine et al., 1997; Kestemont and Mélard, 2000). The withdrawal of live Artemia nauplii from the diet at the time of weaning increases the incidence of cannibalism. Furthermore, compared to other fish species in similar rearing conditions, Eurasian perch juveniles have been found to be highly sensitive to diseases and parasites in experimental intensive culture (Grignard et al., 1996a,b), but differences between perch stocks have not been investigated.

In Experiment 1 of the present study, significant differences in both larval and juvenile survival were observed between the two southern stocks (I and SF) on the one hand and the northern ones (B and NF) on the other. Apart from acclimatisation constraints, the low survival recorded after the larval stage for the southern stocks may be related to the low body weight of larvae at hatching, which limited their access to food and increased their vulnerability to cannibalism. However, as survival was still low in these southern stocks during the early juvenile stage (Experiment 1) and during the on-growing stage (Mélard et al., unpublished data), the hypothesis of low disease resistance cannot be ruled out. Indeed, under the same rearing conditions in Experiments 2 and 3, the values for survival were comparable to juveniles from the F and P stocks and the local B one. Strain differences in disease resistance have been reported for other fish species (McGeer et al., 1991; Pottinger and Moran, 1993; Smitherman et al., 1996; Müller-Belecke and Hörstgen-Schwark, 2000; Henryon et al., 2002). Moreover, significant correlation has been established between survival and size or growth for some fish species, but this relation varied between stocks (Imsland et al., 2002; Henryon et al., 2002).

In the present study, low growth rates were recorded in juveniles from the southern stocks compared to ones from the northern stocks in Experiment 1, and juveniles from the 
P stock grew faster than the F or B juveniles in Experiment 3. This indicates that growth rates in Eurasian perch juveniles in intensive culture vary greatly between different stocks, depending on the geographic origin of fish, as (is the case) in other fish species, too (Smitherman et al., 1996; Jonassen et al., 2000; Imsland et al., 2000; Vandeputte et al., 2002). In studies conducted in the USA by Brown et al. (2002) on yellow perch from different geographic locales, few of the stocks experienced a higher growth rate at optimal temperatures $\left(22^{\circ} \mathrm{C}\right)$. However, at warmer temperatures $\left(28^{\circ} \mathrm{C}\right)$, southern strains outperformed the central and northern strains, and at cooler temperatures $\left(16^{\circ} \mathrm{C}\right)$, northern strains outperformed central and southern ones. These findings may indicate that if yellow perch are grown in outdoor culture systems, local stocks or those from similar latitudes should be considered. Such large-scale comparisons have not been carried out with Eurasian perch strains, except for a comparison between Finnish juveniles and Belgian ones at low temperatures $\left(12\right.$ and $\left.16^{\circ} \mathrm{C}\right)$. However, in that experiment, there were no differences in survival or growth rates between stocks (Mandiki et al., unpublished report).

A high level of variation between different stocks of Eurasian perch may also be discussed according to the results of Experiments 2 and 3 of the present study. In Experiment 2, the growth rates did not differ between the F and B stocks during the early juvenile stage, but later values were higher in the large $\mathrm{F}$ juveniles than in the B ones. The higher growth rates recorded in the large $\mathrm{F}$ juveniles were accompanied by a higher food intake and a higher feed efficiency. In this respect, significant positive correlation was calculated between intra-individual food intake and final body weight in the F stock, not in the $\mathrm{B}$ one, and no difference in the mean share of a meal was observed. In Experiment 3, growth rates in both small and large juveniles were comparable between B and F stocks, but $\mathrm{P}$ stock growth was higher (compared to that of the former two stocks). Thus, lower growth potential for $\mathrm{B}$ and $\mathrm{F}$ stocks may be related to the genetic variation between stocks reported for other fish species such as Atlantic salmon and rainbow trout (Thodesen et al., 2001; Henryon et al., 2002). In Experiment 1 of the present study, it is worthy to note that body weight at hatching did not affect the growth rates; the values did not differ between stocks during the larval stage or were not elevated for juveniles from the B stock, which are the heaviest at hatching (compared to the NF stock). In wild perch populations, the growth dynamics were inconsistently reported between different lakes (Mooij et al., 1999), so no clear relation between initial growth rates and growth parameters at older ages can be established.

In conclusion, the results indicate a high level of variation within and between hatchery stocks in survival, growth rates, and food intake. These depended on the geographic origin of the fish, with the lowest survival and growth potentials appearing in the stocks from southern regions. These findings highlight the interest in evaluating growth and food consumption of different Eurasian perch stocks. Such evaluation is a necessary tool for genetic selection in improving performance in perch aquaculture.

\section{Acknowledgements}

This research was supported by the Walloon Government of Belgium, Direction Générale de la Technologie, de la Recherche et de l'Énergie. The authors are grateful to the 
staff of URBO (T. Mayenne, Y. Mine, A. Evrard), University of Namur, for their assistance.

\section{References}

Baras, E., Malbrouck, C., Houbart, M., Kestemont, P., Mélard, C., 2000. The effect of PIT tags on growth and physiology of age-0 cultured Eurasian perch Perca fluviatilis of variable size. Aquaculture 185, 159-173.

Brown, P.B., Wetzel, J.E., Mays, J., Wilson, K.A., Kasper, C.S., Malison, J., 2002. Growth differences between stocks of yellow perch (Perca flavescens) are temperature dependent. Journal of Applied Aquaculture 12, $43-56$

Carter, C.G., Houlihan, D.F., McCarthy, I.D., 1992. Feed utilisation efficiencies of Atlantic salmon (Salmo salar L) parr: effect of a single supplementary enzyme. Comparative Biochemistry and Physiology 101A, $369-374$.

Craig, F.J., 2000. Percid Fishes: Systematics, Ecology and Exploitation. Blackwell, Oxford (352 pp.).

Fontaine, P., Gardeur, J.N., Kestemont, P., Georges, A., 1997. Influence of feeding level on growth, intraspecific weight variability and sexual growth dimorphism of Eurasian perch Perca fluviatilis L. reared in a recirculation system. Aquaculture 157, 1-9.

Grignard, J.C., Mélard, C., Baras, E., Poirier, A., Philippart, J.C., Bussers, J.C., 1996a. Occurrence and impact of Heteropolaria sp. (Protozoa, Ciliophora) on intensively cultured perch (Perca fluviatilis). Annales Zoologici Fennici 33, 653-657.

Grignard, J.C., Mélard, C., Kestemont, P., 1996b. A preliminary study of parasites and diseases of perch (Perca fluviatilis) in an intensive culture system. Journal of Applied Ichthyology 12, 195-200.

Henryon, M., Jokumsen, A., Berg, P., Lund, I., Pedersen, P.B., Olesen, J.N., Slierendrecht, J.W., 2002. Genetic variation for growth, feed conversion efficiency, and disease resistance exists within a farmed population of rainbow trout. Aquaculture 209, 59-76.

Imsland, A.K., Foss, A., Nævdal, G., Cross, T., Bonga, S.W., van Ham, E.H., Stefansson, S.O., 2000. Countergradient variation in growth efficiency of juvenile turbot. Journal of Fish Biology 57, 1213-1226.

Imsland, A.K., Jonassen, T.M., Langston, A., Hoare, R., Wergeland, H., Fitzgerald, R., Mulcahy, M., Stefansson, S.O., 2002. The interrelation of growth and disease resistance of different populations of juvenile Atlantic halibut (Hippoglossus hippoglossus L). Aquaculture 204, 167-177.

Jonassen, T.M., Imsland, A.K., FitzGerald, R., Bonga, S.W., van Ham, E., Naevdal, G., Stefánsson, M.Ö., Stefansson, S.O., 2000. Geographic variation in growth and growth efficiency of juvenile Atlantic halibut related to latitude. Journal of Fish Biology 56, 279-294.

Kestemont, P., Dabrowski, K., 1996. Recent advances in the aquaculture of percid fish. Journal of Applied Ichthyology 12, 137-200.

Kestemont, P., Mélard, C., 2000. Aquaculture. In: Craig, J.F. (Ed.), Percids Fishes-Systematics, Ecology and Exploitation. Blackwell, Oxford, pp. 191-224.

Kestemont, P., Mélard, C., Fiogbe, E., Vlavonou, R., Massou, G., 1996. Nutritional and animal husbandry aspects of rearing early life stages of Eurasian perch Perca fluviatilis. Journal of Applied Ichthyology 12, 157-165.

Kucharczyk, D., Kujawa, R., Mamcarz, A., Skrzypczak, A., Wyszomirska, E., 1996. Induced artificial spawning in perch, Perca fluviatilis L. using carp pituitary extract and hCG. Aquaculture Research 27, 847-852.

Kujawa, R., Mamcarz, A., Kucharczyk, D., Skrzypczak, A., 2000. An experimental unit for rearing of larval freshwater fish. Folia Universitatis Agriculturae Stetinensis, Piscaria 205, 103-108.

McCarthy, I.D., Carter, C.G., Houlihan, D.F., 1992. The effect of feeding hierarchy on individual variability in daily feeding of rainbow trout, Oncorhynchus mykiss (Walbaum). Journal of Fish Biology 41, 257-263.

McGeer, J.C., Baranyi, L., Iwama, G.K., 1991. Physiological responses to challenge tests in six stocks of Coho salmon (Oncorhynchus kisutch), Canadian. Journal of Fish Aquaculture 48, 1761-1771.

Mélard, C., Kestemont, P., Grignard, J.C., 1996. Intensive culture of juvenile and adult Eurasian perch (Perca fluviatilis): effect of major biotic and abiotic factors on growth. Journal of Applied Ichthyology 12, 175-180.

Mooij, M.W., Van Rooij, J.M., Wijnhoven, S., 1999. Analysis and comparison of fish growth from small samples of length-at-age data: detection of sexual dimorphism in Eurasian perch as an example. Transactions of the American Fisheries Society 128, 483-490. 
Müller-Belecke, A., Hörstgen-Schwark, G., 2000. Performance testing of clonal Orechromis niloticus lines. Aquaculture 184, 67-76.

Nesbø, C.B., Magnhagen, C., Jakobsen, K.S., 1998. Genetic differentiation among stationary and anadromous perch (Perca fluviatilis) in Baltic Sea. Hereditas 129, 241-249.

Nesbø, C.B., Fossheim, T., Vøllestad, A., Jakobsen, S., 1999. Genetic divergence and phylogeographic relationships among Eurasian perch (Perca fluviatilis) populations reflect glacial and postglacial colonization. Molecular Ecology 8, 1387-1404.

Pottinger, T.G., Moran, J.A., 1993. Differences in plasma cortisol and cortisone dynamics during stress in two strains of rainbow trout (Oncorhynchus mykiss). Journal of Fish Biology 43, 121-130.

Romare, P., 2000. Growth of larval and juvenile perch: the importance of diet and fish density. Journal of Fish Biology 56, 876-889.

Smitherman, R.O., Dunham, R.A., Whitehead, P.K., 1996. Selection, hybridization and genome manipulation in Siluroidei. Aquatic Living Resource 9, 93-102.

Talbot, C., Higgins, P.J., 1983. A radiographic method for feeding studies on fish using metallic iron powder as a marker. Journal of Fish Biology 23, 211-220.

Tamazouzt, L., Chatain, B., Fontaine, P., 2000. Tank wall colour and light level affect growth and survival of Eurasian perch larvae (Perca fluviatilis L). Aquaculture 182, 85-90.

Thodesen, J., Gjerde, B., Grisdale-Helland, B., Storebakken, T., 2001. Genetic variation in feed intake, growth and feed utilisation in Atlantic salmon (Salmo salar). Aquaculture 194, $273-281$.

Tyutyunov, Y.A.R., Büttiker, B., Dombrowsky, Y., Staub, E., 1993. Modelling fluctuations and optimal harvesting in perch populations. Ecological Modelling 69, 19-42.

Vandeputte, M., Peignon, E., Vallod, D., Haffray, P., Komen, J., Chevassus, B., 2002. Comparison of growth performances of three French strains of common carp (Cyprinus carpio) using hemi-isogenic scaly carp as internal control. Aquaculture 205, 19-36. 